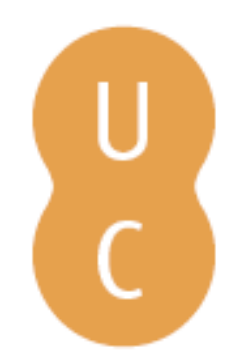

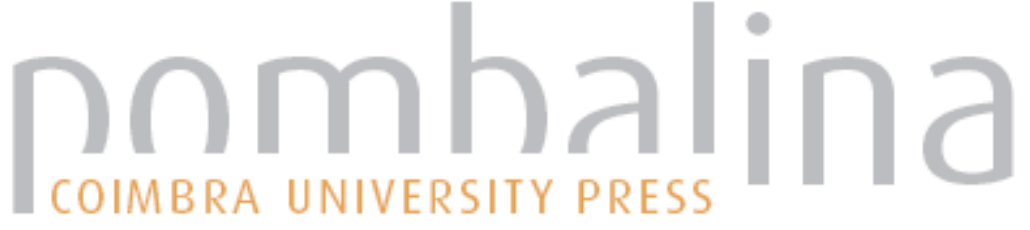

Os poetas e o vice-rei: as poesias de Camões e de António Ferreira dedicadas a D. Constantino de Bragança
Autor(es):
Earle, T. F.
Publicado por: Imprensa da Universidade de Coimbra
URL
persistente:
URI:http://hdl.handle.net/10316.2/30782
DOI:
DOI:http://dx.doi.org/10.14195/978-989-26-0569-2_17
Accessed : $\quad$ 26-Apr-2023 08:12:09

A navegação consulta e descarregamento dos títulos inseridos nas Bibliotecas Digitais UC Digitalis, UC Pombalina e UC Impactum, pressupõem a aceitação plena e sem reservas dos Termos e Condições de Uso destas Bibliotecas Digitais, disponíveis em https://digitalis.uc.pt/pt-pt/termos.

Conforme exposto nos referidos Termos e Condições de Uso, o descarregamento de títulos de acesso restrito requer uma licença válida de autorização devendo o utilizador aceder ao(s) documento(s) a partir de um endereço de IP da instituição detentora da supramencionada licença.

Ao utilizador é apenas permitido o descarregamento para uso pessoal, pelo que o emprego do(s) título(s) descarregado(s) para outro fim, designadamente comercial, carece de autorização do respetivo autor ou editor da obra.

Na medida em que todas as obras da UC Digitalis se encontram protegidas pelo Código do Direito de Autor e Direitos Conexos e demais legislação aplicável, toda a cópia, parcial ou total, deste documento, nos casos em que é legalmente admitida, deverá conter ou fazer-se acompanhar por este aviso.

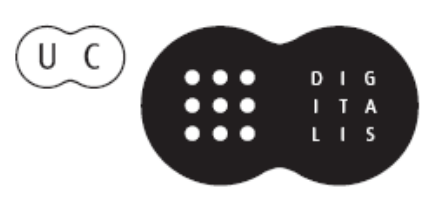




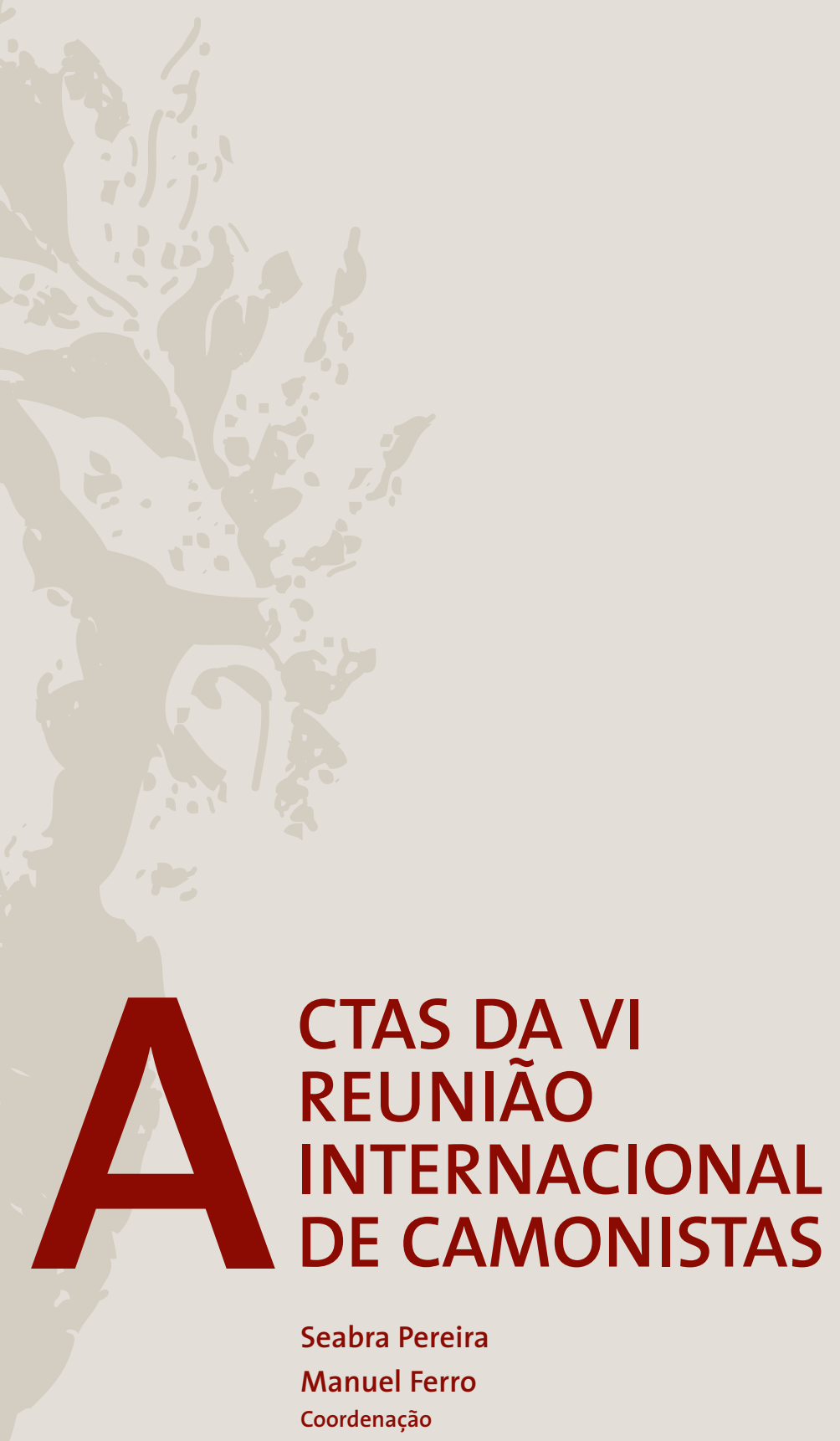




\author{
Rita Marnoto \\ Universidade de Coimbra
}

\title{
SOBRE O SENTIDO DO LIRISMO CAMONIANO
}

1. Na célebre obra Les mots et les choses, Michel Foucault considera a analogia princípio basilar da episteme da «idade clássica», conforme é sabido. Se o carácter abrangente desse sistema teorético facultou o alargamento das suas possibilidades de aplicação e de exploração a campos disciplinares muito vastos, é dessa mesma amplitude que decorre a necessidade de especificar algumas das suas vertentes críticas. Pelo que diz respeito à área dos estudos literários, Klaus W. Hempfer formulou, recentemente, certas reservas à teorização de Foucault, defendendo a necessidade de recorrer aos conceitos de «contextualização» e de "pluralização" para uma pertinente caracterização da episteme renascentista ${ }^{1}$.

Note-se, porém, que o período que Hempfer designa como Renascimento abrange autores que vão de Angelo Poliziano a Pietro Bembo e a Torquato Tasso. Na verdade, tanto os restritivos critérios de selecçáo advogados pelo Cardeal veneziano, nas Prose, como os objectivos que norteiam o Tasso que, nos Discorsi dell'arte poetica, reflecte sobre o cânone dos géneros literários, resultam da ponderação de um conjunto de factores que, tomado por si, é heterogéneo. Mas essa heterogeneidade só pode ser concebida à luz de uma leitura de ordem muito abstracta e generalizante, onde ficam compreendidos não só modelos de construção do saber distintos, como também contextos de índole histórica, literária e social diversificados.

Da preceituação teórica bembesca resulta a inequívoca marginalização do diverso, em nome de uma depuraçáo rigorosa e elitista assente num sistema hierárquico que impóe a repetição do mesmo. O discurso é o microcosmos onde se reflecte a ordem de um macrocosmos perfeito:

\footnotetext{
${ }^{1}$ As consideraçōes de Hempfer são de duas ordens: "Dies ist zum einen der ambige Diskursbegriff, der zugleich die Bedingungen des Redens, und zwar mit oder ohne Bezug auf eine soziale Praxis, und die Bedingungen dieser Praxis selbst meint. [...] Das zweite Problem resultiert aus dem allumfassenden Charakter der vorklassischen episteme, die Foucault über die Kategorie der Ähnlichkeit definiert und die bis ins 17. Jahrhundert reicht. Diese Konzeption ist weder empirisch — wegen der völlig ungenügenden Materialbasis — noch theoretisch - wegen der zeichentheoretischen Fundierung der episteme — 'strak' genug, um die im Selbstverständnis der Zeit manifeste Diskontinuität überspielen zu können. Vielmehr ist der Versuch zu unternehmen, eben diese Diskontinuität epistemologisch zu fundieren." ("Probleme traditioneller Bestimmungen des Renaissancebegriffs und die epistemologische "Wende"': Renaissance Diskursstrukturen und epistemologische Voraussetzungen, hg. v. Klaus W. Hempfer. Stuttgart, Stein, 1993, pp. 27-28).
} 
"e molto meglio faremo noi altresì, se con lo stile del Boccaccio e del Petrarca ragioneremo nelle nostre carte, che non faremo a ragionare col nostro, perciò che senza fallo alcuno molto meglio ragionarono essi che non ragioniamo noi. Né fie per questo che dire si possa, che noi ragioniamo e scriviamo a' morti più che a' vivi. A' morti scrivono coloro, le scritture de' quali non sono da persona lette giamai, o se pure alcuno le legge, sono que' tali uomini di volgo, che non hanno giudicio e così le malvagie cose leggono come le buone, perché essi morti si possono alle scritture dirittamente chiamare, e quelle scritture altresì, le quali in ogni modo muoiono con le prime carte." ${ }^{2}$

Diversa a óptica à luz da qual Tasso perspectiva o conceito de eleição:

"Fra tutte le operazioni de la nostra umana ragione, illustrissimo signore, niuna è più malagevole, niuna più degna d'esser lodata de l'elezione: però che le operazioni fatte a l'improviso possono peraventura come divine e maravigliose esser considerate, ma non meritano lode di maturità e di consiglio e di prudenza; ma l'eleggere è cosa propria de l'uomo che si consigli fra se stesso; e 'l bene eleggere propriissimo del prudente: tanto maggiore nondimeno si mostra la prudenza del far l'elezione, quanto è minore la certezza de le cose elette. Ma qual'è più incerta, quale più instabile, quale più incostante de la materia? Prudentissimo dunque conviene che sia colui il quale non s'inganni ne lo scegliere dove è tanta mutazione e tanta incostanza di cose; e la materia è simile ad una selva oscura, tenebrosa e priva d'ogni luce. Laonde se l'arte non l'illumina, altri errarebbe senza scorta e sceglierebbe peraventura il peggio in cambio del meglio."3

O autor da Liberata parte do reconhecimento do valor desse conceito, que é um princípio basilar da estética bembesca, ciente, porém, de que as dificuldades inerentes ao seu manejo não são de somenos importância. Em seu entender, a aplicação do crivo vê-se perturbada pela mutazione e pela incostanza inerentes à própria materia, e que só a arte pode sublimar. O princípio de imitaçáo continua a erigir-se em referência fundamental, alicerçada, tal como o fora para Poliziano ou para Bembo, a partir da heterogeneidade dos pressupostos em causa. Mas à certeza da relação entre texto e texto, que os vários intervenientes nas polémicas de imitatione nunca puseram em causa, sobrepóe-se a inquietude decorrente não só da inquirição dos elos que ligam modelo e cópia, como também da eclosão, que lhe é concomitante, da materia, a qual, por essência, se encontra submetida às leis da mudança. Se, nas Prose della volgar lingua, a heterogeneidade é reconduzida ao idêntico, neste caso, qualquer tentativa de assimilação ao mesmo se vê perturbada pela irrupção da diferença — do outro. Em causa, duas

\footnotetext{
2 Pietro Bembo, Prose della volgar lingua: Prose e rime, a cura di Carlo Dionisotti. Torino, Unione Tipografico-editrice Torinese, 1978, 2a ed., rist., p. 122.

3 Torquato Tasso, Discorsi del poema eroico: Scritti sull'arte poetica, a cura di Ettore Mazzali. Torino, Einaudi, 1977, 1, p. 168.
} 
interpretaçôes distintas do princípio de analogia, que correspondem à episteme de dois períodos literários também eles distintos: Renascimento e Maneirismo ${ }^{4}$.

A segurança do percurso traçado por Bembo é garantida pela excelência dos modelos (Boccaccio e Petrarca no domínio da prosa e da poesia em vernáculo, Cícero e Virgílio no âmbito da prosa e da poesia neolatinas), pese embora o seu alto preço - a exclusão, do horizonte do homem de Letras, da favella, bem como de todas as manifestaçóes linguístico-literárias conotadas com o volgo. O lirismo renascentista leva a chancela de um Pai que, se não se encontra morto (para retomar a expressão de Bembo), encontra-se ausente da Língua do quotidiano, da Língua materna ${ }^{5}$. Num contexto marcado pela homologação do signo linguístico e dos meios de socialização do produto literário, a intimidade do sujeito não pode ocupar uma posição de primeiro plano. Sintomático, pois, que os cortes operados por Pietro Bembo, na segunda redacção dos Asolani, incidam sobre os passos dotados de mais relevantes implicaçóes pessoais e biográficas ${ }^{6}$. Se a linguagem carrega dentro de si uma ausência que é dupla - a ausência da autoridade que a ditou (Petrarca, os auctores, o Pai) e a ausência do quotidiano, do comum (a favella, a Mãe) —, a repetição do semelhante, da palavra escrita a partir da Palavra (a autoridade do Pai), ao mesmo tempo que passa pela remoção do objecto (do quotidiano, da Língua materna), implica a tentativa de recuperar esse mesmo objecto através da escrita da Escrita.

A cosmovisão maneirista, por sua vez, é marcada pela premência da materia (para utilizar a expressáo de Tasso, incida ela sobre uma realidade linguístico-literária, ou sobre o plano extratextual), fruto da qual são postos em destaque os espaços de não coincidência que brotam dos interstícios da própria homologia. A fractura que assim fica rasgada incide sobre a semelhança, mas sem a negar, ou melhor, servindo-se da diferença para a perquirir. Embora os fundamentos do princípio de analogia não sejam, de forma alguma, postos em causa, a obnubilação dos reflexos especulares que fundamentam a codificação linguístico-literária faz emergir a dissemelhança da semelhança, sobrepondo à relação de identidade entre modelo e cópia um outro tipo de relação, cujos contornos são mais vagos e esfumados. Neste contexto, a perda de confiança na harmonia cósmica que é característica do Maneirismo encontra a sua solução mais clara e radical na valorização da ideia inicial, a verdadeira experiência autêntica, afastada da copia rerum, que tem a sua suprema expressão no Criador.

Platão continua a ser uma referência primordial, mas a interpretação do seu pensamento efectua-se sob uma nova perspectiva. Sintomática, a este propósito, a forma como Stefano Guazzo, personagem do tratado de Gregorio Comanini Il Figino overo del fine della pittura, concebe a distinção platónica entre imitação icastica e imitação fantastica:

\footnotetext{
${ }^{4}$ Para uma definição destes períodos, vd. Vítor Manuel de Aguiar e Silva, Teoria da Literatura. Coimbra, Almedina, 1982, 4a ed., cap. 6. Pelo que diz respeito à situação italiana, vd. Amadeo Quondam, Il naso di Laura. Lingua e poesia lirica nella tradizione del Classicismo. Modena, Ferrara, Panini, Istituto di Studi Rinascimentali, 1991.

5 Cf. ib.: «Nascita della grammatica. Appunti e materiali per una descrizione analitica».

${ }^{6}$ Vd. Pietro Floriani, Bembo e Castiglione. Studi sul classicismo del Cinquecento. Roma, Bulzoni, 1976, p. 89.
} 
"e l'imitazione sappiamo essere di due sorti: una chiamata da lui [Platone] nel Sofista rassomigliatrice overo icastica, e l'altra pur dal medesimo e nell'istesso dialogo detta fantastica. La prima è quella che imita le cose le quali sono, la seconda è quella che finge cose non esistenti [...]"?

Os louvores serão colhidos pela segunda dessas modalidades imitativas, a qual, em sua opinião, desfruta de particular incidência no domínio da arte, tendo por grande exemplo o «ingegnosissimo pittor fantastico e commendabile sommamente» Arcimboldo, ao qual Guazzo não poupa encómios ${ }^{8}$. Na verdade, as suas telas ilustram bem a atracção pela sforciatura e pela novidade morfológica das imagens que é característica da episteme maneirista. Neste sentido, o princípio de analogia reafirma a sua vigência.

2. Camóes é um poeta de transição entre Renascimento e Maneirismo. Os momentos em que a sua poesia se integra na harmonia do ciclo que liga objectividade e subjectividade, ou modelo e cópia, são raros e pontuais. O lirismo brota do cerne de uma inquietude que o leva a interrogar-se, a cada passo, acerca dos signos que maneja. Aliás, em Camóes, a reflexão em torno do sentido da palavra é inerente à própria feitura do discurso poético, entranhando-se nas suas pregas de um modo táo perturbante, que pode levar à delação da falsidade encoberta sob a sua capa.

Perante a Senhora a quem é oferecido um pedaço de cetim para a filha, lamenta "Um dom que anda enxertado / no nome, e nas obras não»" ciente de que através da linguagem é possível enxertar nos nomes qualidades que as obras desmentem. Entre palavras e coisas, abre-se a brecha que póe em causa a linguagem enquanto instrumento de Verdade, que "muitas vezes diz a boca / o que nega o coração» ${ }^{10}$, e que, ao mesmo

7 Trattati d'arte del Cinquecento fra manierismo e controriforma. 3, a cura di Paola Barocchi. Bari, Laterza, 1962, p. 256. Para uma interpretação deste passo à luz da filosofia de Platâo e de Ficino, bem como no contexto do diálogo epocal travado por Comino, Mazzoni e Tasso, vd. ib., pp. 526-28; vd. também Carlo Ossola, Autunno del Rinascimento. "Idea del Tempio» dell'arte nell'ultimo Cinquecento. Firenze, Olschki, 1971.

8 Il Figino overo del fine della pittura, p. 257.

${ }^{9}$ Luís de Camóes, Rimas, texto estabelecido, revisto e prefaciado por Álvaro J. da Costa Pimpão, apresentação de Aníbal Pinto de Castro. Coimbra, Almedina, 1994, 18 Trovas, p. 26.

${ }^{10} \mathrm{Ib}$, 32 Glosa, p. 40. Este tema encontra-se presente em toda a obra de Camôes. Apesar de, nas cançôes, ser desenvolvido com grande profundidade (citem-se, a título de exemplo, os versos da canção décima: «aqui, sombras fantásticas, trazidas / de algumas temerárias esperanças; / as bem-aventuranças / nelas também pintadas e fingidas», p. 225), também nas redondilhas ele é recorrentemente tratado, de forma directa e incisiva, o que muito terá a ver com o facto de a tradição poética peninsular andar associada a uma prática de jogos de palavras e de agudezas susceptível de funcionar como substrato a partir do qual se desenvolve este tipo de reflexóes. Recorde-se o início da cantiga ao mote "Minina dos olhos verdes, / porque me não vedes?»: "Eles verdes são, / e têm por usança / na cor, esperança / e nas obras, não." (12 Cantiga, p. 17); a primeira volta das trovas "a uma Dama que lhe jurava / sempre pelos seus olhos»: "Quando me quer enganar I a minha bela perjura, I para mais me confirmar / o que quer certificar, / pelos seus olhos mo jura. / Como meu contentamento / todo se rege por eles, / imagina o pensamento / que se faz agravo a eles / não crer tão grão juramento." (23 Trovas, p. 31); ou os versos ao mote "Quem se confia em olhos / nas mininas deles vê, / que mininas não têm fé.»: "Enganam ao parecer, / porque, no caso de amar, I são mulheres no matar / e mininas no querer. / Quem em seus olhos se crer, / cem mil graças neles vê; / vê-las, sim, mas não ter fé.» (36 Cantiga, p. 46); vd. também 56 Cantiga, p. 58; 70 Cantiga, pp. 65-66; ou os Disparates, 114 Trovas, pp. 97-102. 
tempo, fundamenta a Verdade que é dita em função da palavra do sujeito que a enuncia - «[...] Quando lerdes / num breve livro casos täo diversos, / verdades puras são, e não defeitos...» ${ }^{11}$.

Transpondo esta questáo para o sistema conceptual peirceano, dir-se-ia que tais interrogativos incidem sobre a relação entre o representamen e o seu objecto, ou seja, sobre o interpretante. Recorde-se que, de acordo com o esquema triádico do filósofo americano, o interpretante, quando considerado numa acepção lata, abarca o sentido do signo. É nesse hiato - isto é, no espaço metafórico de não coincidência que medeia entre significante e significado, entre o signo e o seu referente, entre o poeta e o mundo que o rodeia - que germina a poesia, Verdade da consciência sígnica que a indaga e que a diz.

3. Na Carta a uma dama, a génese da escrita é relacionada com a experiência amorosa e com o ditado de Amor:

"Querendo escrever um dia

o mal que tanto estimei, cuidando no que poria, vi Amor que me dizia:

5 - Escreve, que eu notarei.

E como para se ler não era história pequena a que de mim quis fazer, das asas tirou a pena

10 com que me fez escrever.

E, logo como a tirou, me disse: - Aviva os espritos, que, pois em teu favor sou, esta pena que te dou

15 fará voar teus escritos. E dando-me a padecer tudo o que quis que pusesse, pude, enfim, dele dizer que me deu com que escrevesse

20 o que me deu a escrever. $\mathrm{Eu}$, qu' este engano entendi, disse-lhe: - Que escreverei?

Respondeu, dizendo assi:

- Altos afeitos de ti,

25 e daquela a quem te dei.

E já que te manifesto todas minhas estranhezas, escreve, pois que te prezas,

\footnotetext{
${ }^{11} \mathrm{Ib}$., Soneto 1, p. 117.
} 
milagres dum claro gesto

30 e, de quem o viu tristezas.

Ah! Senhora, em quem se apura

a fé de meu pensamento!

Escutai e estai a tento,

que, com vossa fermosura,

35 iguala Amor meu tormento.

$\mathrm{E}$, posto que tão remota

estejais de me escutar,

por me não remediar,

ouvi, que, pois Amor nota,

40 milagres se hão-de notar ${ }^{12}: "$

Nestas estrofes, que têm uma função introdutória, é explanada a articulação entre duas fases de elaboração do discurso, inuentio e dispositio, utilizando a terminologia da Retórica ${ }^{13}$. Camóes retoma o topos do escriba, consagrado pela abertura da Vita nuova, e que também na poética dos Rerum uulgarium fragmenta assume um importante significado $^{14}$, mas para lhe conferir um outro sentido.

A escrita dantesca nasce da tensão entre o poder do poeta e o poder da linguagem, configurando-se, pois, como reduplicação, como jogo especular, em consonância com as célebres palavras do primeiro capítulo da Vita nuova:

"In quella parte del libro de la mia memoria dinanzi a la quale poco si potrebbe leggere, si trova una rubrica la quale dice: Incipit vita nova. Sotto la quale rubrica io trovo scritte le parole le quali è mio intendimento d'assemplare in questo libello; e se non tutte, almeno la loro sentenzia." 15

12 Ib., 6, pp. 7-8.

${ }^{13}$ Ao manejo dos conceitos de inuentio e dispositio subjazem as consideraçóes de Lausberg: " $A$ inventio não é compreendida como um processo de criação (como em certas teorias poéticas dos tempos modernos), mas sim como um encontrar por meio da recordação (análoga à concepção platónica do saber): os pensamentos, aptos para o discurso, já existem, no subconsciente ou na semi-consciência do orador, como copia rerum, e só precisam de ser despertados por uma hábil técnica mnemónica e mantidos, o mais possivel, conscientes por meio de uma exercitação permanente [...]. Neste caso, a memória é compreendida como uma totalidade espacial, por cujas

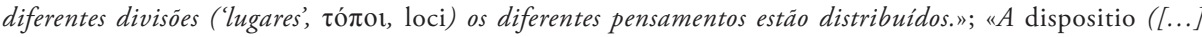
oỉovouía) é constituida pela escolha e ordenação favoráveis ao partido, as quais, no discurso concreto, se fazem dos pensamentos (res), das formulaçóes linguísticas (verba) e das formas artísticas (figurae). Os pensamentos estão à disposição do orador na copia rerum [...], as formulaçóes linguísticas, na copia verborum [...], e as formas artísticas, na copia figurarum [...]» (H. Lausberg, Elementos de retórica literária. $3^{\text {a }}$ ediçăo, tradução, prefácio e aditamentos de R. M. Rosado Fernandes. Lisboa, Fundação Calouste Gulbenkian, 1982, pp. 91 e 95). Para a interpretaçáo do conceito de inuentio, numa perspectiva diacrónica, $v d$. Mariantonia Liborio, «Les glissements progressifs de l'inventio»: Annali dell'Istituto Orientale di Napoli, 26, 1, 1984.

${ }^{14}$ Sobre o sentido da linguagem, em Dante, Petrarca, Giordano Bruno e outros autores mais recentes, vd. Adelia Noferi, Il gioco delle tracce. Studi du Dante, Petrarca, Bruno, il neo-classicismo, Leopardi, l'informale. Firenze, La Nuova Italia, 1979, cujas sugestôes metodológicas foram fundamentais para a elaboração deste trabalho.

15 Opere, a cura di Fredi Chiappelli. Milano, Mursia, ${ }^{2} 1965$, p. 5. 
O sujeito é possuidor do libro de la memoria - o livro que pertence à memória e foi escrito pela memória —, propondo-se organizar a matéria que nele fica contida. Por consequência, a entidade que fala na primeira pessoa é, da mesma feita, o escriba que transcreve as palavras já registadas num primeiro livro, e a personalidade responsável pela sua selecçáo («non tutte»), pelo comentário do seu sentido simbólico («la loro sentenzia») e pelo preenchimento das lacunas nele contidas («assemplare») — ou seja, pela passagem da inuentio à dispositio. Esta operação não se limita a responder, porém, a uma mera necessidade de ordenação cronológica, dada a relevância concedida ao objectivo de construir um iter perfectivo ${ }^{16}$. A palavra nasce, pois, num contexto dialógico onde intervêm, além do próprio escriba, a memória, Amor, Beatriz e Deus. $\mathrm{O}$ amante recebe o saluto através de Beatriz quando é reconhecido pelo absoluto que é Deus.

Na Commedia, por sua vez, a ordem do cosmos é representada como uma estrutura piramidal que tem no seu vértice Deus, o primiloquium inscrito na dimensão dialógica mediante a qual «il soggetto-uomo si istituisce come destinatore / destinatario di una interrogazione in cui l'Altro è l'alterità assoluta di Dio: l'Altro come assoluto» ${ }^{17}$. Daí que o poema culmine com a presença imediata do objecto supremo - a Verdade, Deus, o Outro - , pondo em relevo a parábola da escrita que assim se conclui.

Se, no grande poema dantesco, a palavra é acção (do Outro, do escriba, etc.), mediante a qual é possível ascender até Deus, na poesia de Petrarca a palavra reenvia para ela mesma, expondo a subjectividade do sujeito que a diz. O outro é o vazio que em si contém a interrogação sobre a própria linguagem. Laura é uma criatura inevitavelmente ausente, ou melhor, a criatura cuja ausência fundamenta a sua intensa e eterna presença, através das palavras que lhe dão forma. Existe porque o discurso é construído pelo poeta e é lido pelos destinatários dos seus versos — que é dizer, existe como alieniloquium. O soneto dos Rerum uulgarium fragmenta onde são sugeridos, pela primeira vez, os sons que compóem o seu nome é, da mesma feita, aquele onde fica contida a primeira referência ao mito de Apolo e Dafne — "Quando io movo $i$ sospiri a chiamar voi». Fruto desta imbricada relaçáo de alteridade, a correspondência linear entre Dafne e Laura e entre Apolo e o poeta esvanece-se, pois se o significado de Laura não se esgota na simbologia de Dafne, na célebre canção das metamorfoses também o amante se representa como ninfa perseguida pelo Deus solar, transformado em loureiro ${ }^{18}$. Desta feita, o fio da palavra arrasta-o por um labirinto sem fim, cujo centro aparente se desdobra especularmente através da própria proliferação do dizer. O poeta procura a amada fora de si, quando afinal ela é uma alteridade impossível, constrói um discurso sobre um objecto que é também ele um discurso, e, ao repetir a sua angústia, assegura a perenidade do desejo. Assim se compreende que, nessa

${ }^{16}$ Conforme mostrou Michelangelo Picone, «La Vita nuova sará, in questo senso, la manifestazione di un'analoga prospettiva supra-personale e universale assunta dalla vicenda dell'io nell'ambito della ricerca soteriologica della civiltà romanza.» ("Rito e narratio nella Vita nuova»: Miscellanea di studi in onore di Vittore Branca. 1. Dal Medioevo al Petrarca. Firenze, Olschki, 1983, p. 144).

${ }^{17}$ Adelia Noferi, Il gioco delle tracce [....], p. 10.

18 «e i duo mi trasformaro in quel ch'i'sono, / facendomi d'uom vivo un lauro verde, / che per fredda stagion foglia non perde» (Canzoniere, testo critico e introduzione di Gianfranco Contini, annotazioni di Daniele Ponchiroli. Torino, Einaudi, 1964, 23. 38:40.). 
mesma canção, Actéon não seja representado no momento em que é devorado pelos cáes, mas como cervo que foge eternamente dos seus latidos ${ }^{19}$. O objecto de desejo é, por essência, inatingível, visto que, se, por um lado, Petrarca não tem confiança no itinerarium mentis ad Deum seguido por Dante, por outro lado, intersectando-se o objecto de desejo com o discurso, daí resulta a infinita perpetuaçáo do dizer.

Neste âmbito, o modo como explora o topos do escriba erige-se em sinal sintomático do processo de citação e de desconstrução da poética dantesca que fica contido nas páginas dos Rerum uulgarium fragmenta. É o que resulta da estrofe inicial da canção $127^{20}$ :

"In quella parte dove Amor mi sprona conven ch'io volga le dogliose rime, che son seguaci de la mente afflicta. Quai fien ultime, lasso, et qua' fien prime?

5 Collui che del mio mal meco ragiona mi lascia in dubbio, sí confuso ditta. Ma pur quanto l'istoria trovo scripta in mezzo 'l cor (che sí spesso rincorro) co la sua propria man de' miei martiri,

10 dirò, perché i sospiri parlando àn triegua, et al dolor soccorro.

Dico che, perch'io miri mille cose diverse attento et fiso, sol una donna veggio, et 'l suo bel viso."

A possibilidade de «re-dizer» implica um processo de mediação que em muito ultrapassa o jogo especular do proemium dantesco. A perspectiva supra-pessoal inerente à estrutura em pirâmide fruto da qual a narratio culmina no primiloquium, através de um iter perfectivo ritualizado, não é facilmente conciliável com uma poética centrada sobre a expressão das várias cambiantes de uma intimidade lírica. Aliás, considerações da mesma ordem poderiam ser feitas a propósito da Carta a uma dama. No plano da inuentio, Petrarca começa por adaptar a célebre imagem descrita no Fedro, mas invertendo-lhe os pólos. Platão concebia a alma enquanto tríade formada por dois cavalos alados, um dócil e racional, outro indomável e sensual, e pelo seu auriga ${ }^{21}$.

19 "Vero dirò (forse e’ parrà menzogna) / ch'i' senti" trarmi de la propria imago, / et in un cervo solitario et vago / di selva in selva ratto mi trasformo: / et anchor de' miei can' fuggo lo stormo.» (ib., 23. 156:60.).

${ }^{20}$ Cf. Adelia Noferi, «La canzone 127»: Lectura Petrarce, 1, 1981-82; pelo que diz respeito ao processo de citação e "desconstrução" da poética dantesca, vd. p. 378. Sobre a relação entre Dante e Petrarca, vd. também Michele Feo, «Petrarca, Francesco»: Enciclopedia dantesca. Roma, Istituto della Enciclopedia Italiana, 1973, bem como a bibliografia apresentada; e Marco Santagata, Per moderne carte. La biblioteca volgare di Petrarca. Bologna, Il Mulino, 1990, «Parte prima».

21 "L'uno dei cavalli, dicemmo, è nobile, e l'altro no [...]. Ora l'uno, e cioè quello in miglior forma, è di figura dritta e snella, ha la cervice alta, le froge regali, il mantello bianco e gli occhi neri, ama la gloria temperata e pudica, ed è amico dell'opinione verace; lo si guida senza frusta solo con l'incitamento e la ragione. Ma l'altro corsiero ha una struttura contorta e massiccia, messa insieme non si sa come, ha forte cervice, collo 
Neste caso, porém, o cavaleiro é Amor e o cavalo passa a ser o sujeito dominado pela paixão - «[...] Amor mi sprona» (1.). Todavia, as dúvidas que nutre são também partilhadas pelo próprio Amor — «mi lascia in dubbio, sí confuso ditta» (6.). O seu ditado é confuso porque a posição que ocupa não é dominante em relação ao sujeito. Ambos partilham do mesmo nível de conhecimento e das mesmas dúvidas, envolvidos como se encontram num diálogo denso, mas que traduz uma experiência não isenta de sobressaltos. O ditado de Amor náo pode ser, pois, como o é na Vita nuova, garante da Verdade do contado (5:6.), visto ser posta em causa a possibilidade de conceber uma estrutura narrativa à luz de uma ordem sequencial una e coesa - e, enquanto tal, ritualizada ("Quai fien ultime, lasso, e qua' fien prime?», 4.). A passagem da inuentio para a dispositio (4.) suscita dúvidas que incidem quer sobre a própria possibilidade de «re-dizer», quer sobre os fundamentos lógicos e cronológicos do discurso ${ }^{22}$.

Também na Carta a uma dama a passagem da inuentio para a dispositio é como que perturbada pelas circunstâncias em que se efectua o ditado de Amor, adquirindo, porém, implicaçóes que em muito superam a letra do texto dos Fragmenta.

Inuentio e dispositio coincidem parcialmente, enquanto subordinadas à égide de Amor, o que é linguisticamente traduzido pela homonínia entre locus a re, no plano da inuentio, e locus ab instrumento, no plano da dispositio - a "pena" (9:10. e 19:20.). Apesar disso, o ditado de Amor de forma alguma se erige em garante da coerência lógica da escrita. Se, por um lado, a sua «nota» é previamente definida revelação de estranhezas (26:27.), como se de uma sforciatura se tratasse, por outro, nela fica contida uma série de casos que ora encontram paralelo na experiência sentimental do poeta, ora náo, ou seja, ora funcionam como locus a simile, ora funcionam como locus a contrario.

Reentram no primeiro grupo a comparação entre os povos que habitam junto da fonte do Ganges e se alimentam do odor das flores que aí existem, e o poeta, que

tozzo, froge vili, mantello nero ed occhi chiari e sanguigni, compagno di insolenza e di vanità, peloso fino alle orecchie, sordo e a stento dà retta alle sferzate della frusta. Quando l'auriga alla vista del volto amoroso, tutto infiammato l'animo di quella sensazione, è invaso dalla smania e dal pungolo della passione, il cavallo docile all'auriga, costretto ora come sempre dal pudore, si trattiene dal lanciarsi sull'amato, ma il cavallo sordo alle sferzate della frusta, scalpitando è spinto di forza e, mettendo in grande imbarazzo il compagno e l'auriga, li costringe ad avanzare verso l'amato e a rammemorare i piaceri dell'amore afrodisiaco. E $i$ due da principio resistono, infuriati d'esser forzati ad azioni mostruose e proibite, ma alla fine, non trovando un freno al male, spinti ad avanzare cedono e lasciano fare ciò che gli è imposto. E si fanno vicini all'amato e ne vedono la folgorante visione. A tal vista la memoria dell'auriga è ricondotta alla natura della bellezza e di nuovo la vede alta su un sacro soglio a fianco della Temperanza, e al ricordo di questa visione l'auriga preso dal timore e dalla venerazione cade riverso allindietro: perciò è costretto a trarre indietro le redini con tale violenza che $i$ cavalli si accosciano sulle anche, senza resistenza il corsiero docile, ma a forza il violento.» (Platone, Fedro 253 c-254 c: Opere complete. 3. Parmenide, Filebo, Simposio, Fedro. Bari, Laterza, 1971, pp. 255-56).

22 A confrontar com a interpretaçáo levada a cabo por Dante, no Convivio, da imagem platónica dos cavalos e do auriga: «Veramente questo appetito conviene essere cavalcato da la ragione; ché sì come uno sciolto cavallo, quanto ch'ello sia di natura nobile, per sé, sanza lo buono cavalcatore, bene non si conduce, cosi questo appetito, che irascibile e concupiscibile si chiama, quanto ch'ello sia nobile, a la ragione obedire conviene, la quale guida quello con freno e con isproni, come buono cavaliere. Lo freno usa quando elli caccia, e chiamasi quello freno Temperanza, la quale mostra lo termine infino al quale è da cacciare; lo sprone usa quando fugge, per lui tornare a lo loco onde fuggire vuole, e questo sprone si chiama Fortezza, o vero Magnanimitate, la quale vertute mostra lo loco dove è da fermarsi e da pugnare.» (26. 5:7.: Opere, p. 281). 
vive da contemplação daquela que ama; ou a comparação entre o braço do pescador, imobilizado pelo veneno colocado na sua cana, e os seus olhos, absorvidos pela amada. Já o exemplo do doente que é curado pela visão de uma ave, quando confrontado com a situação do amante que vê a sua Fénix, e «quanto mais, mais deseja» (80.); ou o exemplo da fonte que condena à cegueira quem junto dela jura falso, ao contrário da amada, que, ao ouvir as verdades que vão na alma do poeta, o impede de a ver, se integram no segundo desses paradigmas. Neste sentido, a «nota» de Amor corresponde a uma amplificatio das estranhezas a que fora feita alusão nas estrofes introdutórias.

A imagem do escriba, com as suas ressonâncias dantescas, gera, pois, uma espécie de efeito de trompe l'oeil, na medida em que as próprias alteraçóes da lógica do discurso decorrem da proximidade entre inuentio e dispositio. Mas é também neste ponto que Camóes vai mais além do que Petrarca, e não só pela maior importância que confere ao acto de escrita, como também pelo modo segundo o qual se intersectam semelhança e diferença, ordem e desordem, prazer e dor decorrentes da escrita - através de uma linha serpentina cuja dinâmica decorre da reversibilidade dos vários momentos que integra. Creio, pois, que o princípio da dialéctica camoniana, tal como o concebeu Jorge de Sena ${ }^{23}$, é também extensível ao plano hermenêutico.

A inuentio incide sobre a memória de uma experiência pessoal anterior ( que tanto estimei», 2.) e de uma experiência que é correlata ao ditado de Amor ( $E$ dando-me a padecer / tudo o que quis que pusesse», 16:17.). O instrumento de escrita é a matéria da escrita, a "pena». A «fermosura» feminina é o "tormento" do amante ("que, com vossa fermosura, / iguala Amor meu tormento», 34:35.). E, enfim, o poeta é Amor ("Quantos contrários consente / Amor, por mais padecer!», 171:72.). Tal como a experiência constrói a escrita, assim também a escrita constrói a experiência.

A palavra reenvia para ela mesma, mas enquanto reflexo de reflexos animado por um dinamismo inesgotável, que em muito supera o sentido do texto dos Rerum uulgarium fragmenta. Se, na canção "In quella parte dove Amor mi sprona», Amor é situado ao mesmo nível do sujeito, na Carta a uma dama as funçóes assumidas por essas duas entidades integram-se dialecticamente: "Que escreverei?» (22.), "De quem me irei queixando, / ou quem direi que m’ engana»? (96:97.).

"Que me quereis, perpétuas saudades? / Com que esperança ainda m' enganais?»" 24 ; Que levas, cruel morte?» 25 ; "De quem me queixarei, que tudo mente? / Mas eu que culpa ponho às esperanças / onde a Fortuna injusta é mais que os erros?» 26 . Observa Blanchot:

"Trouver, chercher, tourner, aller autour: oui, ce sont des mots indiquant des mouvements, mais toujours circulaires. Comme si la recherche avait pour sens de s'infléchir nécessairement en tournant. Trouver s'inscrit sur cette grande "voûte" céleste qui nous a donné les premiers modèles du mouvant immobile. Trouver, c'est chercher par le rapport au centre qui est proprement l'introuvable. [...]

23 "A poesia de Camóes - ensaio de revelação da dialéctica camoniana»: Trinta anos de Camóes. 19481978 (estudos camonianos e correlativos). 1. Lisboa, Ediçôes 70, 1980.

${ }^{24}$ Rimas, Soneto 107, p. 170.

${ }^{25} \mathrm{Ib}$., Soneto 158, p. 195.

${ }^{26} \mathrm{Ib}$., Soneto 109, p. 171. 
Errer, c'est tourner et retourner, s'abandonner à la magie du détour. L'égarré, celui qui est sorti de la garde du centre, tourne autour de lui-même, livré au centre et non plus gardé par lui." 27

4. Uma das consequências da reversibilidade dialéctica que é característica do sentido do lirismo camoniano consiste na dificuldade em construir um relato de fundo biográfico enformado por uma ordem narrativa sequencial e coesa. A vontade de contactar com uma experiência originária leva a fantasia e a inuentio a deambularem por uma série de imagens que surpreende pela sua novidade morfológica, mas cuja autenticidade passa pela constatação de que a materia é, por essência, instável. Continuando a utilizar as palavras de Tasso, poder-se-ia dizer que também na poesia camoniana a arte ilumina essa inconstância, na medida em que a reproduz, em nome de um diálogo que se quer verdadeiro.

Os sobressaltos da inuentio incidem sobre a dispositio e perturbam-lhe o andamento, instituindo a ordem da desordem:

"que do penar a ordem desordeno, porque náo mo consente o sofrimento. ${ }^{28}$

mas a dor do desprezo recebido,

que a fantasia me desatinava,

estes enganos punha em desconcerto". 29

O narrativo deixa lugar ao metafórico, como acontece naquele tipo de projecção biográfica que Beaujour designa como autoportrait (auto-retrato) ${ }^{30}$. Nele fica contido um sistema de reenvios, de sobreposiçóes, ou de correspondências entre elementos homólogos e substituíveis, cuja aparência é de descontinuidade, como se se tratasse de uma montagem, em oposição a uma sintagmática narrativa.

A experiência inaugural do autor do auto-retrato é a do vazio - um vazio que, em Camóes, vai sendo rasgado, e, da mesma feita, vai sendo colmatado, com a "pena» através da qual "Amor deu ao poeta com que escrevesse o que lhe deu a escrever», parafraseando a Carta a uma dama (19:20.) ${ }^{31}$ "[...] Tourner et retourner, s'abandonner à la magie du détour [...] livré au centre et non plus gardé par lui», escreve Blanchot. Construção e obscurecimento de copia rerum, representação do sujeito através do confronto com o outro - o alieniloquium de Petrarca, l'Autre-Même de Montaigne, ou aquele espaço autobiográfico suprimido por Pietro Bembo, entre a primeira e a segunda redacção dos Asolani.

\footnotetext{
${ }^{27}$ Maurice Blanchot, L'entretien infini. Paris, Gallimard, 1969, p. 36.

28 Rimas, Soneto 21, p. 127.

29 Ib., Canção 10 , p. 225.

${ }^{30}$ M. Beaujour, «Autobiographie et autoportrait»: Poétique, 32, 1977.

31 Seria sugestivo ilustrar o lugar desempenhado pela abertura ao feminino, no âmbito do preenchimento desse vazio, a partir da leitura da cantiga a mote "Quem disser que a barca pende / dir-lhe-ei, mana, que mente.». Mas muitos são os problemas de autoria suscitados pelo seu texto, pela primeira vez publicado na terceira parte das Rimas, em 1668
} 
Neste contexto, através do auto-retrato institui-se um paradigma ao qual é sempre possível acrescentar elementos homólogos. Discours en miettes - chama-lhe Beaujour ${ }^{32}$. Rerum unlgarium fragmenta - é o título que Petrarca dá ao livro de poemas sobre o qual se debruça até ao fim dos seus dias, para deixar gravado, no Vat. Lat. 3195, o último dos códices em que trabalhou, o silêncio das páginas em branco, onde tencionava registar outras composiçóes, interpostas entre a primeira e a segunda partes do cancioneiro. Uma contínua saudade ${ }^{33}$, uma vida pelo mundo em pedaços repartida ${ }^{34}$, feita de males em pedaços ${ }^{35}$, confessa o peregrino vago e errante:

"agora, peregrino vago e errante, vendo naçôes, linguages e costumes, Céus vários, qualidades diferentes, só por seguir com passos diligentes a ti, Fortuna injusta, que consumes as idades, levando-lhe diante uma esperança em vista de diamante, mas quando das mãos cai se conhece que é frágil vidro aquilo que aparece." ${ }^{36}$

— "C'est probablement cela, errer: aller hors de la rencontre» ${ }^{37}$.

Actéon não é o cervo que escapa eternamente à laceração, como na canção das metamorfoses de Petrarca, mas o caçador cujo desdobramento de alteridade (o cervo, o outro) coincide com a redução do alieniloquium à sua ínfima expressão (o eco, o mesmo):

"Cos olhos e co gesto lhes falava, que a voz humana já mudada tinha.

Qualquer deles por ele então chamava, e a multidáo dos cáes contra ele vinha.

Que viesse ver um cervo, lhe gritava;

Actéon, aonde estás? Acude asinha!

Que tardar tanto é este (lhe dizia)?

- É este, é este, o eco respondia." 38

- E o mesmo e o outro só fora do centro podem coincidir. A questáo permanece e prevalece,

32 "Autobiographie et autoportrait», p. 444.

33 Rimas, Elegia 2, p. 238.

34 Ib., Canção 9, p. 221.

35 Ib., Canção 10, p. 228.

36 Ib., p. 227.

37 Maurice Blanchot, L'entretien infini, p. 37.

38 Rimas, Écloga 7, p. 378. 
“[...] fascinante, elle règne par l'attrait de sa présence qui est présence de quelque chose qui ne devrait pas être là — qui, en vérité, n'est pas là - et devant quoi l'on ne peut pas être là, demeurer, se tenir droit: présence d'une image qui vous transforme en l'énigme d'une image. [...] Elle ne permet pas qu'on l'entende; on peut seulement la répéter, la réfléchir sur un plan où elle n'est pas résolue, mais dissoute, renvoyée au vide d'où elle a surgi. C'est là sa solution: elle se dissipe dans le langage même qui la comprend." 39

5. Esta espiral que gira sobre si mesma, envolvendo a génese do lirismo camoniano, para projectar o sujeito no vazio da palavra que o diz, além de arrastar consigo os grandes temas e motivos da obra do poeta, vincula a própria feitura do discurso.

No início da cançấo décima, assistimos ao fazer e desfazer da trama que sustém a escrita:

"Vinde cá, meu tấo certo secretário dos queixumes que sempre ando fazendo, papel, com que a pena desafogo!

As sem-razóes digamos que, vivendo,

5 me faz o inexorável e contrário

Destino, surdo a lágrimas e a rogo.

Deitemos água pouca em muito fogo;

acenda-se com gritos um tormento

que a todas as memórias seja estranho.

10 Digamos mal tamanho

a Deus, ao mundo, à gente e, enfim, ao vento,

a quem já muitas vezes o contei, tanto debalde como o conto agora; mas, já que para errores fui nascido,

15 vir este a ser um deles não duvido.

Que, pois já de acertar estou tão fora, não me culpem também, se nisto errei.

Sequer este refúgio só terei:

falar e errar sem culpa, livremente.

20 Triste quem de tâo pouco está contente!

Já me desenganei que de queixar-me

não se alcança remédio; mas quem pena,

forçado lhe é gritar, se a dor é grande. ${ }^{40}$

A primeira estrofe rodopia em torno das possibilidades sublimativas do canto. $\mathrm{O}$ papel proporcionará o desafogo da pena, mas é «água pouca em muito fogo» (7.), de tâo grande que é o mal. O que de excessivo em si contém o significado - o «mal tamanho» (10.) - transborda da capacidade expressiva do significante. Então, a «falta

\footnotetext{
39 Maurice Blanchot, L'entretien infini, p. 22.

${ }^{40}$ Rimas, Canção 10, p. 223.
} 
do significante», associada ao "excesso do significado», desencadeia a proliferaçâo do próprio significante. O grito sai forçado, conforme é dito nos primeiros versos da segunda estrofe.

A canção décima é, de entre as cançôes de Camôes, aquela que tem não só um maior número de estrofes, como também um maior número de versos por estrofe e um maior número de decassílabos por estrofe. O seu esquema formal segue o da cançáo 23. do Canzoniere, «Nel dolce tempo de la prima etade», retomado por Jacopo Sannazaro ( Spirto cortese, che sì bella spoglia» ${ }^{41}$ ) e por Pietro Bembo ("Alma cortese, che dal mondo errante" ${ }^{2}$ ) em chave fúnebre, e igualmente utilizado por Garcilaso, na composição " $\mathrm{El}$ aspereza de mis males quiero" 43 . Camóes modela o esquema da cançấo das metamorfoses, mas nem alude directamente aos exemplos da mitologia antiga patentes em "Nel dolce tempo de la prima etade", nem faz da morte cerne dos seus versos, como o haviam feito Bembo e Sannazaro. Em "Vinde cá, meu tão certo secretário", temas e motivos do lirismo camoniano são perspectivados em função de uma outra trama metamórfica, através da qual a morte se converte em vida, e vice-versa - a da escrita. $\mathrm{O}$ seu comiato tematiza, precisamente, o prolongamento e a expansão do canto:

"Nô mais, Canção, nô mais; qu' irei falando

sem o sentir, mil anos. E se acaso

te culparem de larga e de pesada,

não pode ser (lhe dize) limitada

a água do mar em tão pequeno vaso.

Nem eu delicadezas vou cantando

co gosto do louvor, mas explicando

puras verdades já por mim passadas.

Oxalá foram fábulas sonhadas!" ${ }^{44}$

De outra forma, também a expansão do significante pode ser moderada pela necessidade de silenciar o significado, ou porque a sua explicitaçáo iria corromper os gostos, conforme se diz no final da Carta a uma dama,

"Faz-me este mal infinito

não poder já mais dizer,

por não vir a corromper

os gostos que tenho escrito

cos males que hei-de escrever.

Não quero que se apregoe

mal tanto para encobrir,

porque, em quanto aqui se ouvir,

${ }^{41}$ Rime. Padova, Giuseppe Comino, 1723, pp. 432-33.

42 Rime: Prose e rime, pp. 623-30.

43 Obras completas con comentario, edición crítica de Elias L. Rivers. Madrid, Castalia, 1981, pp. 190-202.

${ }^{44}$ Rimas, Canção 10, p. 229. 
nenhuma outra cousa soe

que a glória de vos servir." 45 ,

Ou porque a amargura carregada pelo significante coloca o sujeito junto ao abismo da morte,

"Canção, nô mais, que já não sei que digo;

mas porque a dor me seja menos forte,

diga o pregão a causa desta morte." 46

Significante e significado, uoluptas canendi e uoluptas dolendi, rodopiam um sobre o outro, sustentando-se mutuamente. O prolongamento do discurso arrasta o risco de autodestruiçáo, como acontece com o cisne, que eleva o seu mais belo canto antes de morrer. Mas esta ave, ao mesmo tempo que lamenta o fim dos seus dias, exprime o desejo de que a sua vida se prolongue ${ }^{47}$ :

"O cisne, quando sente ser chegada

a hora que póe termo a sua vida,

música com voz alta e mui subida

levanta pola praia inabitada.

Deseja ter a vida prolongada,

chorando do viver a despedida;

com grande saudade da partida,

celebra o triste fim desta jornada.

Assi, Senhora minha, quando via

o triste fim que davam meus amores,

estando posto já no extremo fio,

com mais suave canto e harmonia

discantei pelos vossos disfavores

La vuestra falsa fe, y el amor mío." ${ }^{48}$

Escreve Petrarca acerca do amor que o consome: «Di mia morte mi pasco, et vivo in fiamme» ${ }^{49}$. Esta situação encontra o seu correspondente genérico na poesia de Camóes, dado que também neste caso a recusa da morte está para a defesa do princípio de prazer - que é dizer, para a eternização do desejo. Mas, para o poeta português, morte e vida sustêm-se no seu âmago, de modo intrínseco, fruto da relação dialéctica que os

45 Ib., 6, p. 12.

46 Ib., Canção 2, p. 207.

${ }^{47}$ E recorde-se também o comiato da terceira cançáo: "Canção de cisne, feita n' hora extrema: / na dura pedra fria / da memória te deixo, em companhia / do letreiro de minha sepultura; / que a sombra escura já m’impede o dia.» (ib., p. 209).

48 Rimas, Soneto 54, p. 143.

49 Canzoniere, 207. 40. Vd., sobre este tema, Adelia Noferi, "Voluptas canendi, voluptas scrivendi: divagazioni sulla vocalità in Petrarca»: Paradigma, 7, 1986. 
une, e que é entretecida através dessa palavra que "[...] dissoute, renvoyée au vide d'où elle a surgi [...] [,] se dissipe dans le langage même qui la comprend»:

"Assi vivo; e se alguém te perguntasse,

Canção, como não mouro,

podes-lhe responder que porque mouro." 50

O discanto, na sua dimensão dialógica, exibe todas as dúvidas, todas as perplexidades e todas as incertezas próprias da cosmovisão maneirista:

"Mas com quem falo, ou que estou gritando,

pois não há nos penedos sentimento?

Ao vento estou palavras espalhando;

a quem as digo, corre mais que o vento." 51

- Entre uoluptas canendi e uoluptas dolendi, entre pulsão de vida e pulsão de morte, "Cette coupure de la chaîne signifiante est seule à vérifier la structure du sujet comme discontinuité dans le réel, 52 .

O fio do labirinto feito com as palavras do nome de Laura é perturbado pela irrupção dessa descontinuidade, pelos obstáculos que minam a sua trajectória e engrandecem a complexidade da errância, forçando o discurso a descrever movimentos bruscos ao longo das grandes volutas da espiral que o garante e o póe em causa. Com elas se cruza uma série de outras vias que não leva, necessariamente, de Apolo a Dafne.

6. Se o poeta engana com palavras o desejo, é porque também a palavra é objecto de desejo:

"E assi, de enleada, a esperança

se satisfaz co bem que náo alcança.

Se com razóes escuso meu remédio,

sabe, Canção, que porque não vejo,

engano com palavras o desejo." 53

O desejo esboça-se na margem onde a procura rasga a carência. Essa margem é aberta pela procura, cujo apelo incondicional incide sobre o espaço do Outro, enquanto falta decorrente da carência, dada a impossibilidade de encontrar satisfação universal: a chamada angústia, diz Lacan. Margem que, apesar de linear, deixa a descoberto a vertigem, "[...] pour peu qu'elle ne soit pas recouverte par le piétinement d'élephant du caprice de l'Autre» ${ }^{54}$. É este capricho que introduz o fantasma do Poder absoluto,

\footnotetext{
50 Rimas, Canção 9, p. 223.

51 Ib., Écloga 7, p. 379.

52 Jacques Lacan, Ecrits II. Paris, Seuil, 1971, p. 160.

53 Rimas, Canção 1, p. 205.

54 Jacques Lacan, Ecrits II, pp. 174-75.
} 
não do sujeito, mas do Outro visado pela procura. Com este fantasma, sobrevem a necessidade do seu domínio através da Lei.

Na poesia camoniana, também o desejo não é (nem seria) susceptível de ser satisfeito através de nenhuma das formas que o atrai, ou porque, na sua vertigem, as excede, ou porque supera os seus limites angustos, ou porque, em virtude de tantos outros motivos, um e outras náo se coadunam, e a procura continua a rasgar a margem onde se gera o desejo - entre signo linguístico e referente, entre Verdade e poesia, entre inuentio e dispositio, entre vazio inicial e auto-retrato, entre acçâo e conhecimento, entre destinador e destinatário, entre sujeito e objecto.

$\mathrm{O}$ que deseja o poeta?

"Aquele não sei quê, que espira não sei como, que, invisível saindo, a vista o vê, mas para o compreender não acha tomo;

o qual toda a Toscana poesia, que mais Febo restaura, em Beatriz nem em Laura nunca via"55

Através desta referência ao topos do inefável, é expresso um princípio fundamental da poética camoniana, cujos pressupostos hermenêuticos remontam a Santo Agostinho ${ }^{56}$. Se o inefável é fonte de todos os efáveis, então não se poderá esgotar em nenhum dos efáveis. Aquilo a que o poeta aspira - aquele não sei quêe — não há tomo que o compreenda. Nem o exemplo literário de Dante, nem o modelo cunhado por Petrarca o poderiam traduzir em palavras.

A angústia que atormenta o sujeito vincula-o a uma procura que não lhe permite reconduzir o seu trabalho à arte do mesmo — a autoridade do cânone literário ditado por Dante e Petrarca ${ }^{57}$, a autoridade do Pai ausente, diria Quondam, «[...] le piétinement d'élephant du caprice de l'Autre» que introduz o fantasma do Poder absoluto e a concomitante necessidade do seu domínio através da Lei, pontifica Lacan. Apesar de, na ode sexta, se vislumbrar o caminho da ascenção ao Bom e ao Belo ideais através dos sentidos, nos termos em que fora postulado por Ficino na Theologia platonica, o final desta composição perpetua o fantasma do Poder absoluto do Outro:

"O campo não o esmaltam

flores, mas só abrolhos

o fazem feio; e cuido que lhe faltam

ouvidos para mim, para vós olhos.

Mas faça o que quiser o vil costume;

55 Rimas, Ode 6, p. 271.

56 Sobre a filosofia agostiniana da linguagem e as suas repercussões, vd. João Maria André, Sentido, simbolismo e interpretação no discurso de Nicolau de Cusa. Universidade de Coimbra, 1992, cap. 10 e 11.

57 Vd. Rita Marnoto, O petrarquismo português do Renascimento e do Maneirismo. Universidade de Coimbra, 1994, cap. 4. 4. e 5. 3. 
que o sol, que em vós está,

na escuridão dará mais claro lume." 58

Aquilo a que o poeta aspira é um infinito -

"aquele gesto imoto e repousado,

que estando n'alma propriamente escrito,

não pode ser em verso trasladado;

aquele parecer que é infinito

para se compreender de engenho humano,

o qual ofendo em quanto tenho dito,

me inflama o coração dum doce engano,

m'enleva e engrandece a fantasia,

que não vi maior glória que meu dano." 59

- Que, como tal, não pode ser alcançável, por essência, através do finito. fala -

Mas é no mundo do finito que o poeta se move, é sobre a sua experiência que

"Metido tenho a mão na consciência,

e não falo senão verdades puras

que m’ ensinou a viva experiência." 60

- E é sobre um objecto que, sob o ponto de vista cultural, simboliza o finito no que tem de fragmentário e de lábil, que concentra o seu desejo - a mulher.

Ao afirmar que "La femme, ça ne peut s'écrire qu'à barrer La. Il n'y a pas La femme puisque [...] de son essence, elle n'est pas toute» ${ }^{61}$, Lacan perpetua uma tradição antropológica cujas raízes se perdem na origem dos tempos. De acordo com esse legado cultural, a mulher é definida a partir de uma oposição (masculino / feminino) que depois se reduplica e se desdobra, por si, em muitas outras dualidades: alma / sentidos, espírito / matéria, verdade / mentira, divino / diabólico ${ }^{62}$. Segundo Platão, a matéria, que é feminina, caracteriza-se por ser, da mesma feita, inteligível e incompreensível, potência absorvedora, que recebe no seu seio outro género, e potência geradora, que cria as formas ${ }^{63}$. Esta concepção será retomada por Aristóteles e Plotino, que a associam

58 Rimas, Ode 6, p. 271.

59 Ib., Ode 4, p. 243.

${ }^{60} \mathrm{Ib}$., Soneto 93, p. 163.

${ }^{61}$ Apud Adelia Noferi, Il gioco delle tracce [....], pp. 122-23.

${ }^{62}$ Cf. ib., p. 117; e Ph. Lacoue-Labarthe, "L'irreprésentable»: Poétique, 21, 1975.

63 "[...] quella natura che riceve tutti $i$ corpi [...] si deve dire che è sempre la stessa, perché non perde affatto la sua potenza, ma riceve sempre tutte le cose, e in nessun modo prende mai una forma simile ad alcuna di quelle cose che entrano in essa: perché essa di sua natura è la materia formativa di tutto, che è mossa e figurata dalle cose che vi entrano, e appare, per causa di esse, ora in una forma e ora in un'altra»; "[...] dicendo ch'è una specie invisibile e informe e ricettrice di tutto, e partecipe in qualche modo oscuro dell'intelligibile, e incomprensibile, non cinganneremo." (Platone, Tim., 50 b-c e 51 a: Opere complete. 6. Clitofonte, La Repubblica, Timeo, Crizia, pp. 404 e 405). 
à dispersão e ao plúrimo, ao ser e ao não ser $^{64}$. $\mathrm{Na}$ Bíblia, por sua vez, diz-se que a mulher é formada a partir de uma costela de Adão ${ }^{65}$.

$\mathrm{Na}$ lírica camoniana, a figura feminina é representada através de imagens de índole dispersiva, sendo-lhe frequentemente atribuídas características que são, entre si, contraditórias. A mulher é associada ao que de mais fluido existe na natureza: aos raios da aurora, na terceira canção e nas glosas ao mote "Pastora da serra"; às águas que se dispersam pelos campos; às profundidades que guardam irremediavelmente o seu corpo ${ }^{66}$. A evocação da sua presença ou da sua figura implica, quase sempre, um distanciamento espácio-temporal que esbate a recordação, imergindo a imagem numa atmosfera de contornos evanescentes.

Mas esta fluidez representativa encontra-se intimamente relacionada com um outro aspecto da sua caracterizaçáo, que diz respeito à cisão por planos e vertentes absolutamente diferenciados. Ela é dotada da "celeste formosura" de uma Circe feiticeira ${ }^{67}$. Tem forma humana e cintila espíritos divinos, é fera e ama, cria o poeta, de pequeno, com veneno, e duplica-se na figura daquela que ele há-de amar em idade matura $^{68}$ - o que só poderá ser compreendido em virtude da dualidade que é própria do

64 "Difatti, essendovi un divino e un bene e un ente desiderabile, noi da una parte affermiamo che la materia è il loro contrario, ma dall'altra che essa ha la disposizione a desiderarli e ad accoglierli in conformità con la propria natura. Da ciò conseguirebbe che il contrario sia proteso alla propria distruzione. Eppure nemmeno la stessa forma può desiderare né se stessa, per il fatto che non ne ha bisogno, né il contrario (per il fatto che $i$ contrari son tra loro causa di distruzione), ma tale desiderio lo ha la materia, come la femmina ha desiderio del maschio o il brutto del bello, tranne che essa non è brutta di per sé, ma per accidente, né femmina se non per accidente. E, in un senso, essa si corrompe e si genera, in un altro no. Infatti, in relazione a ciò che è in essa, di per se stessa à corrotta (perché quello che in essa è corrotto è la privazione); ma, in relazione alla potenza, essa né si genera, né si distrugge di per sé, bensì è necessariamente incorrutibile e ingenerata. Se, invero, fosse generata, occorrerebbe che le soggiacesse qualcosa, dalla cui immanenza essa risulterebbe; ma proprio questo soggiacere è la sua natura, e quindi essa è prima di essere generata (giacché io chiamo materia il primo comune sostrato di ciascuna cosa e ciò dalla cui immanenza non accidentale un qualcosa è generato);" (Fis. 192 a: Aristotele, Opere. 3. Fisica, Del cielo. Bari, Laterza, 1973, p. 24).

"La materia [...] [è] non essere in senso schietto e proprio, vale a dire un'ombra e una parvenza di massa; una pura ansia a far da substrato; un riposante che non sta quieto; uno che invisibile in se stesso, sfugge altresí a ciò che vorrebbe vederlo; e qualora uno non veda, gli sorge dinanzi, ma se quegli scruta attentamente, ritorna invisibile; e fa affiorare su di sé, perpetuamente, i contrari: piccolo e grande, meno e piú, difetto ed eccesso; fantasma evanescente che, d'altro canto, non riesce neppure a svanire; vogliam dire che neppure in questo mostra vigore, giacché non trasse vigore di sorta dallo Spirito e, per contro, essa nacque proprio nella mancanza di tutto ciò che dicesi essere. Perciò, in tutto che di sé professa, ella è bugiarda: e se appare grande, ella è piccola; se preponderante, è sopraffatta; e l'essere che si rivela nelle sue sembianze è, di fatto, non essere: quasi gioco fuggente: ond'è che le cose, le quali apparentemente s'ingenerano in essa, non son che trastulli, vere ombre nell'ombra, come in uno specchio l'oggetto appare in un punto mentre è situato altrove: esso, ben gremito all'apparenza, è vuoto; e non ha nulla, ma sembra aver tutto." (Plotino, Enn. 3. 7.: Enneadi. 2, prima versione integra e commentario critico di Vicenzo Cilento. Bari, Laterza, 1948, pp. 93-94).

65 "Immisit ergo Dominus Deus soporem in Adam. Cumque obdormisset, tulit unam de costis eius et replevit carnem pro ea; et aedificavit Dominus Deus costam, quam tulerat de Adam, in mulieram et adduxit eam ad Adam»; "Dixitque Adam: Mulier, quam dedisti sociam mihi, ipsa dedit mihi de ligno, et comedi." (Gen. 2. 21:22.; e 3. 12.: Nova vulgata bibliorum sacrorum. Sacros. oecum. Concilii Vaticani II, 1986, editio typica altera, pp. 7 e 8)

${ }^{66}$ Rimas, Canção 3, p. 208; 5, Cantiga, p. 6; 10, Cantiga, p. 16; e Soneto 86, p. 159.

${ }^{67} \mathrm{Ib}$., Soneto 90, p. 161.

68 Ib., Canção 10 , pp. 224-25. 
feminino, fruto da qual o processo de geração se desdobra em processo de degeneração. Não é uma Laura, nem uma Beatriz - é Catarina, Guiomar, Isabel, Leanor.

A impossibilidade de aceder ao infinito pela via do finito imerge o discurso numa descontinuidade que, associada à circularidade dialéctica que caracteriza o universo camoniano, vai protelando a possibilidade de ascender ao primiloquium e à resposta final que encerra a Verdade suprema. O momento da obra de Camóes em que o poeta mais claramente se aproxima desse Infinito etéreo é representado pelas redondilhas «Sôbolos rios». A ascese tem por determinante, porém, o corte de todas as amarras que ligam o sujeito ao plano do terreno, o que implica a recusa de todos os «afeitos [...] / que encendem alma e engenho",

“porque não podemos nós,

nem com eles ir a Vós,

nem sem Vós tirar-nos deles" 69

- "Cette entente qui regarde, ce jeu de l'entente et du voir est jeu où se joue 'ce qu'ily a de plus haut et de plus profond': L'Un. La question de l'être qui s'éteint comme question est question qui s'éteint dans l'entente de l'Un. L'Un, le Même restent les premiers, les derniers mots. Pourquoi cette référence à l'Un comme référence ultime et unique? En ce sens, la dialectique, l'ontologie et la critique de l'ontologie ont le même postulat: toutes trois se remettent à l'Un» ${ }^{70}$. Desta feita, a superação da questáo dialéctica processa-se em conformidade com as premissas do próprio sistema dialéctico que lhe dá forma, sem necessidade de recurso a soluçôes de continuidade.

Apesar do movimento circular que subjaz a esta projecção muito dever, nos seus fundamentos, ao pensamento neoplatónico, não é, uma vez mais, nas páginas de Marsilio Ficino e dos seus sequazes que vamos encontrar o seu directo correspondente filosófico. De acordo com o ideário exposto na Theologia platonica, princípio e fim coincidem porque cada coisa tende para a sua origem, que é Deus, em nome da perfeição e da harmonia que regem o universo. Se nada é inútil, todo o apetite deseja o Bem, ou seja, Deus, e é transformado em certeza de posse. O percurso ascendente que assim fica delineado processa-se, pois, de forma contínua e sem rupturas, ao contrário do que acontece em «Sôbolos rios». As implicaçóes perfectivas da dialéctica ascencional ficiniana traduzem a confiança que é própria da cosmovisão renascentista, mas são substancialmente alheias às estranhezas do discurso camoniano, bem como à fragmentação e à descontinuidade que lhe são próprias. Só depois de despojado "[...] do vil contentamento / cá deste mundo visivel» o homem poderá ascender ao "divino aposento» Etéreo $^{71}$.

O pensamento de Camóes é essencialmente sincrético. A forma como concebe a circularidade dialéctica poderá ter alguns pontos de contacto com o neoplatonismo da escola de Chartres, nomeadamente com o dualismo de Bernardus Silvestris, muito

\footnotetext{
${ }^{69}$ Ib., 117, Super flumina, p. 112.

${ }^{70}$ Maurice Blanchot, L'entretien infini, pp. 33-34.

${ }^{71}$ Rimas, 117, Super flumina, pp. 113 e 114.
} 
próximo de Calcídio e dos herméticos ${ }^{72}$. Aliás, em 1463, Ficino traduziu o Corpus hermeticum, muito provavelmente por instância do próprio Cosimo de' $\mathrm{Medici}^{73}$. Mas a fundamental impossibilidade de ascender ao inefável e ao infinito através do efável e do finito não decorre, conforme muitas vezes se faz crer, do neoplatonismo ficiniano, mas daquele filáo neoplatónico que se desenvolve a partir da filosofia e da hermenêutica de Santo Agostinho.

Esta vertente espiritualista enforma vastas áreas da cultura portuguesa de Quinhentos, assumindo importantes repercussóes não só no campo religioso, como também no campo do conhecimento científico. Valha por todas a remissão para os trabalhos de Jaime Cortesão onde é colocada a tónica quer sobre o papel desempenhado pelos Franciscanos, quer sobre a grande divulgação do pensamento de Ramón Lull e do lulismo, durante o período dos Descobrimentos ${ }^{74}$. Recorde-se, além disso, que se, em termos filosóficos, a crise espiritual que se abateu sobre o Portugal de finais do século XVI, inícios do século XVII, levou a uma reviviscência do ascetismo medieval, esta faixa cronológica corresponde, em termos literários, ao período do Maneirismo, o qual se caracteriza pela recuperação de muitos dos elementos da linguagem poética da Idade Média ${ }^{75}$.

Segundo Lull, o falso amor gera-se a partir de uma rede de contradiçóes ${ }^{76}$ que gira circularmente sobre si mesma, sem oferecer possibilidades de redenção, pois «Plus

72 Sobre a escola de Chartres e o dualismo de Bernardus Silvestris, vd. Eugenio Garin, Studi sul platonismo medioevale. Firenze, Le Monnier, 1958, cap. 1. Aliás, Paul Oskar Kristeller, em Renaissance thought and its sources, ed. by Michael Mooney. New York, Columbia University Press, 1979, p. 117 s., chama a atenção para a revitalização dos pensadores medievais que, no século XVI, é levada a cabo em Portugal e Espanha.

73 Pelo que diz respeito à divulgaçáo do pensamento hermético, no período do Renascimento, e ao papel desempenhado por Marsilio Ficino, vd. Eugenio Garin, Ermetismo del Rinascimento. Roma, Editori Riuniti, 1988.

${ }^{74}$ Cf., além do mais, "O Franciscanismo e a expansão geográfica» e "O espírito laico e a expansẫo da cristandade»: História dos Descobrimentos portugueses. 1. Lisboa, Círculo de Leitores, 1979. Acerca da difusão do lulismo, na Literatura e na Cultura portuguesas do século XVI, vd. também: Abílio Martins, «A Literatura árabe e a Corte imperial»: Brotéria, 26, 1, 1938 (e, pelo que diz respeito ao período medieval, vd. id., "A filosofia de Raimundo Lulo na Literatura Portuguesa medieval»: Brotéria, 34, 5, 1942); Mário Martins, «Em torno da História da Filosofia cristã espanhola»: Revista portuguesa de Filosofia, 3, 1947, bem como a bibliografia indicada; e António José Saraiva, História da Cultura em Portugal. 1. Lisboa, Jornal do Foro, 1950, cap. 6 e 7.

75 Cf. Vítor Manuel de Aguiar e Silva, Teoria da Literatura, p. 440 s. A influência do pensamento de Ramón Lull sobre a poesia espanhola ao divino é documentada através dos trabalhos de: Helmut A. Hatzfeld, "The influence of Ramon Lull and Jan von Ruysbroeck on the language of the spanish mystics»: Tradition. Studies in ancient and medieval history, thought and religion. 4, ed. by Stephan Kuttner and Anselm Strittmatter, New York, Cosmopolitan Science \& Art Service Co., Inc., 1946; Miriam Thérèse Olabarrieta, S.C.N., M.A., The influence of Ramon Lull on the style of the early spanish mystics and Santa Teresa. Washington, D.C., The Catolic University of America Press, 1963; e Louis Sala-Molins, La philosophie de l'amour chez Raymond Lulle. Service de reproduction des thèses de l'Université de Lile III, 1971.

76 "L'ami désirait avec tant d'intensité les louanges et les honneurs de son aimé, qu'il se demandait s'il s'en souvenait. Et il hä̈ssait avec tant d'intensité les déshonneurs de son aimé, qu'il se demandait s'il les hä̈ssait. Et l'ami restait donc perplexe entre l'amour et la crainte de son aimé [...]. L'ami se mourait de plaisirs et vivait de langueurs. Et les plaisirs et les tourments s'assemblaient et s'unissaient pour être une seule chose dans la volonté de l'ami. C'est pourquoi l'ami vivait et mourait dans le même temps." (Lulle, Livre de l'ami et de l'aimé: L'arbre de philosophie d'amour, Le livre de l'ami et de l'aimé et choix de textes philosophiques et mystiques, traduction, introduction et notes par Louis Sala-Molins. Paris, Aubier, Montaigne, 1967, p. 373). Cf. o excerto citado com a imagem lacaniana da margem. 
contrariété de mal amour est touchée, plus elle multiplie le vice et le péché» 77 . O verdadeiro amor é o que "[...] dit à l'ami de ne pas le faire durer en aimant les biens particuliers, qui durent peu, mais les biens généraux, qui durent beaucoup" 78 .

$\mathrm{Na}$ Historia de las ideas estéticas en España, Menéndez y Pelayo afirma que o pensamento dos sequazes de Ramón Lull teve grande influência sobre a poesia de Ausias March, bem como sobre a lírica espanhola do século XVI, conforme o mostra a obra poética de Boscán e Garcilaso. Eis como este crítico sintetiza as linhas mestras do pensamento de um insigne membro da escola lulista, Sabunde:

"Siendo el amor de Dios y el amor proprio la causa de todos los demás amores, infiérese que de ellos depende todo conocimiento de los bienes y de los males, porque el amor de Dios es el principio para conocer todos los bienes del hombre. El amor de Dios es luz iluminante. Por el contrario, el amor proprio, como es tinieblas y obscuridad por su naturaleza, se esconde y se obscurece á si mismo, y obscurece y ciega el entendimiento, para que no vea el amor en sí. Quien tiene tal amor ignora todos los bienes y males del hombre. El amor de Dios, por ser su objeto uno tan solo y común á todos los hombres, produce amor y concordia entre ellos. El amor proprio, por no ser su objeto uno y común á todos los hombres, los separa, y engendra división y discordia. [...] el gozo que nace del amor proprio es sofístico y deceptivo, y lleva siempre oculta cierta manera de tristeza. Pero tal cual sea, este gozo todavía nos atrae, puesto que por causa del placer nos movemos y buscamos toda cosa, y nadie se engańa sino por falsa razón de deleite. De onde se infiere que el gozo es apetecible por sí mismo, y que el gozo malo atrae, no por lo que tiene de malo, sino por la razón de deleite que lleva consigo. El alma ama y desea naturalmente la hermosura, la limpieza y la amenidad, y aborrece la torpeza, la inmundicia, la obscuridad y la deformidad." 79

Tal como, para Sabunde, entre amor por Deus e amor próprio não há conciliação possível, dado que o primeiro é Uno e comum a todos os homens, e o segundo dispersivo, assim nas páginas do lirismo camoniano afectos terrenos e comunhão com o Divino são colocados em planos distintos. Pelo contrário, Marsilio Ficino e os neoplatónicos renascentistas sustentavam que através da contemplação sensitiva do Belo era possível ascender até à felicidade Divina, sendo o Belo e o Bom indissociáveis. Além disso, de acordo com o discípulo de Lull, a atracção que desencadeia o amor próprio não anda associada ao apetite de mal, mas antes à vontade de experimentar um prazer que posteriormente se vem a revelar nefasto, porque o que deseja é fátuo

77 Arbre de philosophie d'amour: ib., p. 260.

78 Ib., p. 252.

${ }_{79}$ Marcelino Menéndez y Pelayo, Historia de las ideas estéticas en España. 2. Madrid, Hernando (S. A.), 1928, 4a ed. corregida y aumentada, pp. 214 e 218. Aliás, este crítico relaciona o contraponto entre aspiração ao infinito e confronto com o plano do finito, patente na poesia de Ausías March, com o pensamento luliano: "Si com aquell qui per sa in finitat / no pot esser de res finit content, / [...] / axi Amor vos amant m'asegura, / tot lo restant del mon me fá gran nossa." (ib., p. 231). 
e enganador. É este o perno em torno do qual volteia a dialéctica camoniana, «o mal que tanto estimei» (2.), conforme escreve na Carta a uma dama:

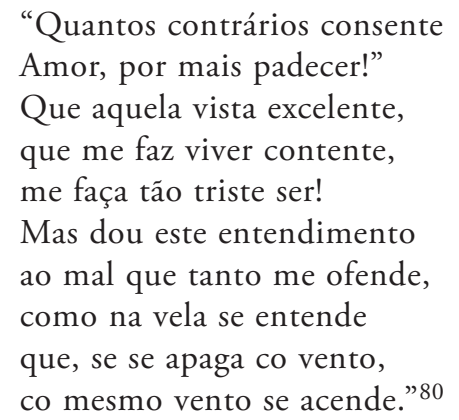

Sob este ponto de vista, Camôes não segue exactamente nem os trilhos de Ficino, que considerava bons ambos os cavalos através dos quais Platão representara a alma, nem o exemplo de Platão, que entendia que um deles era sensato e outro desvairado. $\mathrm{O}$ apetite, tomado por si, nada tem de mal, o mal está naquilo por que é atraído - o lábil, o finito, o fragmentário.

São os fragmentos deste mosaico que o discurso vai tentando recompor, ao mesmo tempo que relança ao infinito um desejo que nunca poderá ser saciado. Se o sujeito busca o infinito através do finito e do fragmentário, o amor não poderá ser, de forma alguma, gratificante. Mais do que um amor em palavras, com palavras, é um amor por entre as palavras. O discurso camoniano é, pois, um discurso descentrado, quer sob um ponto de vista biográfico - já que é fora do centro que o mesmo e o outro coincidem - , quer sob o ponto de vista existencial - por ter como centro declarado um objecto finito, quando aquilo a que o sujeito aspira é um infinito —, quer sob um ponto de vista lírico — visto ter por centro aparente a figura feminina, quando o seu verdadeiro centro é o poeta, o desejo e o canto. "En ce sens, raconter est le tourment du langage, la recherche incessante de son infinité. Et le récit ne serait rien d'autre qu'une allusion au détour initial que porte l'écriture, qui la déporte et qui fait que, écrivant, nous nous livrons à une sorte de détournement perpétuel ${ }^{81}$.

7. "E tu também, ó Dafne, que trouxeste primeiro ao monte o doce verso agreste." 82

Emblema da palavra poética, na Écloga dos faunos Dafne converte-se em imagem da irredutibilidade da distância que separa o desejo da sua satisfação. Camóes não é, nem poderia ser, o amante que, na canção 23, dos Rerum uulgarium fragmenta, se metamorfoseia em loureiro. Se, para Petrarca, a palavra é o fio do labirinto do

\footnotetext{
${ }^{80}$ Rimas, 6, p. 11.

${ }^{81}$ Maurice Blanchot, L'entretien infini, p. 564.

${ }^{82}$ Rimas, Écloga 7, p. 374.
} 
discurso, em Camóes a palavra plasma a descontinuidade inerente à génese e à feitura do próprio discurso.

Actéon mira-se nas águas. Vê espelhada a série de exemplos descrita pelo Sátiro, nessa bucólica, vê Diana, e, ao mesmo tempo, vê-se a si próprio, transformado em cervo:
"Tudo isto Actéon viu na fonte clara, onde a si de improviso em cervo viu; que quem assi destarte ali o topara, que se mudasse em cervo permitiu." ${ }^{3}$

Nas águas claras, as imagens desdobram-se umas sobre as outras, como reflexos de reflexos aos quais se sobrepóe a metamorfose de Actéon. Daqui decorre, pois, a instauração do ponto de vista que Deleuze designa différentiel. O devir infinito converte o princípio de analogia em espaço do eterno détour, ao mesmo tempo que define a distância que separa Camóes quer de Platão, quer da normatividade bembesca e da dupla ausência que carrega, a autoridade e o quotidiano. A premência do sujeito no discurso arrasta o simulacro, a angústia, a vertigem:

"Le simulacre inclut en soi le point de vue différentiel; l'observateur fait partie $d u$ simulacre lui-même, qui se transforme et se déforme avec son point de vue. Bref, il y a dans le simulacre un devenir-fou, un devenir illimité comme celui du Philèbe où 'le plus et le moins vont toujours de l'avant', un devenir toujours autre, un devenir subversif des profondeurs, habile à esquiver l'égal, la limite, le Même ou le Semblable: toujours plus et moins à la fois, mais jamais égal. Imposer une limite à ce devenir, l'ordonner au même, le rendre semblable - et, pour la part qui resterait rebelle, la refouler le plus profond possible, l'enfermer dans une caverne au fond de l'Océan: tel est le but du platonisme dans sa volonté de faire triompher les icônes sur les simulacres." ${ }^{4}$

$\mathrm{O}$ discurso camoniano não é alicerçado a partir da ordem do mesmo. Actéon, o caçador, apenas pode observar Diana obliquamente, no espelho das águas, e Diana, por sua vez, é reflexo do deus-sol, Apolo, o eterno cantor de Dafne:

"Però a nessun pare possibile de vedere il sole, l'universale Apolline e luce absoluta per specie suprema ed eccellentissima; ma sí bene la sua ombra, la sua Diana, il mondo, l'universo, la natura che è nelle cose, la luce che è nell'opacità della materia, cioè quella in quanto splende nelle tenebre. De molti dunque, che per dette vie ed altre assai discorreno in questa deserta selva, pochissimi son quelli che s'abbattono al fonte de Diana [...] [,] gli Atteoni alli quali sia dato dal destino di posser contemplar la Diana ignuda, e dovenir a tale che dalla bella disposizione del corpo della natura invaghiti in tanto, e scorti da que' doi lumi del gemino splendor de divina bontà e bellezza, vegnano trasformati in cervio, per quanto non siano piú cacciatori ma caccia. Perché il fine ultimo e finale di questa venazione è de venire allo acquisto di quella fugace e selvaggia preda, per cui il predator dovegna preda, il cacciator doventi caccia's5

${ }^{83} \mathrm{Ib}$., p. 378.

${ }^{84}$ Gilles Deleuze, Logique du sens. Paris, Minuit, 1969, p. 298.

${ }^{85}$ Giordano Bruno, Dialoghi italiani. Dialoghi metafisici e dialoghi morali, nuovamente rist. con note da Giovanni Gentile, 3a ed. a cura di Giovanni Aquilecchia. Firenze, Sansoni [s. d.], pp. 1123-24. 
- Lê-se no final do segundo diálogo dos Eroici furori. Diana resplandece na superfície aquática, e o caçador só a pode espreitar escondido. O Uno espelha-se nas partes que o compóem - caçar e ser caçado, ver e ser visto, aspirar ao uno e ser condenado à laceraçáo. Desta feita, no sistema conceptual de Giordano Bruno, Actéon converte-se em imagem da coincidentia opositorum ${ }^{86}$ por excelência - anseia à Unidade, mas apenas a pode entrever de forma esparsa, nos fragmentos de Apolo reflectidos em Diana, na sua imagem-outra projectada nas águas.

Quando, na Écloga dos faunos, Actéon observa no espelho da fonte clara a metamorfose das ninfas, também o desejo latente sublimado em poesia se vê reconduzido à parcialidade fragmentária do discurso e do sujeito que o constrói. Todavia, o movimento dialéctico donde brota o sentido, ao mesmo tempo que inviabiliza a coincidentia opositorum, impede-o de se fixar em formas estáveis. "Tanta mutazione e tanta incostanza di cose» só através da imitaçáo fantastica pode ser dita.

${ }^{86}$ Desta feita, gera-se um mecanismo de reversibilidade mediante o qual a ruptura da unidade se faz um só com a recomposição dos fragmentos: «Itaque si quemadmodum uno perfracto speculo propter partium multiplicationem animalium animarum multiplicata sunt supposita, si accidat iterum partes omnes in unam massam coalescere, unum erit speculum, una forma, una anima, sicut si omnes fontes, flumina, lacus et maria in unum concurrant oceanum, unus erit Amphitrites." (Iordani Bruni Nolani, Lampas triginta statuarum: Opera latine conscripta, curantibus F. Tocco et H. Vitelli. Florentiae, Le Monnier, 1891, p. 60). Consequentemente, o sentido adquire uma «multiplicabilidade» e uma «metaforicidade» infinitas, e a metamorfose assume uma importância proeminente, ao representar a construção e a destruição das formas. $V d$. Adelia Noferi, Il gioco delle tracce [....], cap. 3.; e, sobre as implicaçôes especulares da autobiografia, na sua relação com a filosofia, $v d$. Michele Ciliberto, "Bruno allo specchio. Filosofia e autobiografia nel Cinquecento": Rinascimento, s. 2, 34, 1994. 